\title{
Effectiveness of Using Discovery Learning Model Assisted Tracker on Improvement of Physics Learning Outcomes Observed From Students' Initial Knowledge
}

\author{
Nurfadilah*, Dwi Sulisworo $^{* *}$, Guntur Maruto**, Suritno Fayanto** \\ ${ }^{*}$ Department of Master in Physics Education, Universitas Ahmad Dahlan \\ ** Department of Master in Physics Education, Universitas Ahmad Dahlan
}

DOI: 10.29322/IJSRP.10.01.2020.p9755

http://dx.doi.org/10.29322/IJSRP.10.01.2020.p9755

\begin{abstract}
The purpose of this study is to determine the effectiveness of the use of discovery-assisted discovery learning models to improve physics learning outcomes in terms of students' initial knowledge. This research was conduct at Senior High School 1 Talibura in the academic year 2019/2010. This research is an experimental research that uses a quasi-experimental design consisting of a nonequivalent (pretest-posttest) control group design. Sampling uses simple random sampling so that two sample classes obtained, namely level XI MIA 1 as an experimental class and class XI MIA 2 as a control class. The first knowledge instrument and learning outcomes are subjective tests (essays) that have been tested for validity and reliability. Hypothesis testing using ANCOVA test. Based on data analysis, the results showed that there was an influence of the tracker assisted discovery hearing model on student physics learning outcomes, where $\mathrm{F}_{\text {count }}$ is higher than $\mathrm{F}_{\text {table }}(4,484>3,20)$ with the significant value obtained is smaller than the significance level $(0,017<0,05)$. From this study, we can conclude that the discovery-assisted discovery learning model tracker is handy to be used in physics learning to improve student physics learning outcomes.
\end{abstract}

Index Terms- Discovery learning model, tracker, physics learning outcomes, initial knowledge

\section{INTRODUCTION}

$P^{\mathrm{h}}$ hysics is the study of natural phenomena or phenomena. Physics has become one of the most fundamental sciences of knowledg ${ }^{1}$. Physics expected to be able to direct the educated generation to have good observation and reasoning abilities. However, in learning physics, students tend to experience obstacles. Students consider physics as a complicated subject. Perspectives that physics is involved is the reason for the decline in students' interest in physics².

The students' initial knowledge determines the readiness of students in learning. Initial experience is the knowledge that students have before participating in the lesson. Initial knowledge becomes essential for teachers to know before starting education. Through fundamental knowledge, it can be known as the extent to which students already know the material to present. One study group indeed consists of students with different school backgrounds, so they can ascertain that their initial knowledge is different too.

Although some of the concepts of physics formed through mathematical analysis, in the end, the theory developed must teste through experiments. Experimental activities with a discovery learning approach result in students being able to improve and enhance their skills and cognitive processes. If involved continuously in learning discovery, students will better understand and be able to develop aspects ${ }^{3}$. On the other hand, discovery through experimentation becomes one of the methods often used to facilitate understanding. Still, in reality, this method encounters obstacles such as limited time, inadequate tools, and a lack of students' responses to problems encountered. In this case, it is necessary to use technology as a medium for learning physics.

In learning physics, supporting media needed that can facilitate the understanding of the material. The use of multimedia is considered able to improve student learning outcomes ${ }^{4}$ — various advantages offered by technology to enhance the quality of physics learning. The use of technology in learning physics is more productive than the lecture and demonstration methods ${ }^{5}$. Technology can improve and develop the professional abilities of teachers, can be used as a source of learning, as a tool for learning interactions, as well as a forum for learning. Technology can improve and develop the professional abilities of teachers, can be used as a source of knowledge, as a tool for learning interactions, as well as a forum for learning ${ }^{6}$. However, in reality, both students and teachers have not been able to utilize technology as a learning medium. Technology is still used only as a means of communication and social interaction. Most students use technology only to update news on social media. As a result, much of their study time not used as it should and wasted.

Problems are various in learning physics impact on the low learning outcomes of students. In Senior High School 1 Talibura, for example, physics learning outcomes are relatively small compared to other natural science subjects. Various attempts were made by 
the teacher to improve student learning outcomes, but the results were not satisfactory. This condition spurred researchers to make reforms by optimizing the use of technology as a medium for learning physics. With technology, the material will present in the form of videos about physical phenomena. The video will be recorded by students who are then analyzed using a tracker to obtain accurate data. The tracker allows students to analyze the motion of objects in the video by making a trail that follows the movement of objects in video ${ }^{7}$. In groups of students who were taught using video and analyzed using a tracker experienced increased competence and knowledge ${ }^{8}$. That way, it is expected that physics learning outcomes can increase.

Associated with the above view, the researcher is interested in researching "the effectiveness of the discovery-assisted discovery learning model towards improving physics learning outcomes in terms of the students' initial knowledge."

\section{THEORETICAL REVIEW}

\section{A. Discovery Learning Model}

Discovery learning is a fundamental inquiry approach ${ }^{9}$. The teaching method is inquiry-based and is considered a constructivist based approach to education. A literature review shows that discovery learning occurs whenever students are not provided with conceptual understanding and must find it independently and only with the material provided ${ }^{10}$. Discovery Learning emphasizes students to find the concept of knowledge6. In the process of finding, students guided to do a series of stages of learning from observing to organizing their findings into a theory of knowledge. Discovery learning encourages students to be active agents in their learning process ${ }^{11}$. Education helps students to find out various sources through observation and not just being told ${ }^{12}$. The aim is to build concepts and gain knowledge from experience. The experience introduced to increase relevance and meaning. Students guided by the teacher who directs questions to problems so as enable students to draw simple relationships, generalizations, or conclusions ${ }^{9}$.

\section{B. Conventional Learning Model}

Conventional learning is a teaching and learning process that commonly used in schools ${ }^{13}$. In traditional knowledge, students placed as learning objects that act as passive recipients of information ${ }^{14}$. Conventional learning, in general, has certain peculiarities, for example, prioritizing memorization rather than understanding, emphasizing numeracy skills, prioritizing results rather than process, and teacher-centered teaching ${ }^{15}$.

From some understanding, it concluded that the conventional learning model is a teacher center learning model, prioritizing results rather than processes. In this study, students placed as objects rather than subjects, so students are less confident in expressing their opinions. A learning concept that is used by teachers in conveying material in the usual way. This learning still carried out without utilizing technology as a medium education. This learning always carried out the assumption knowledge transferred in full from the mind of the teacher to the students.

\section{Tracker}

A tracker is a software that can analyze, and model motion and optical phenomena are free and developed by Open Source Physics (OSP) using the Java framework ${ }^{16}$. Through a tracker, educators and or students can quickly analyze real-world problems, especially on the topic of motion and optics that are sometimes impossible to do without the help of technology.

\section{Initial Knowledge}

Fundamental knowledge is a collection of individual expertise and experience gained during their life journey and which they will bring to new learning experience ${ }^{17}$. Student initial knowledge is a collection of information that can bridge the extent to which other understandings can be used ${ }^{18}$.

The initial knowledge possessed by each student is different. Different individuals state different information according to their ways and present information differently in their memory based on their initial experience and knowledge ${ }^{19}$. Student fundamental knowledge plays a vital role in learning because it supports the ease of students in accepting and understanding a new material or concept in education. Student's initial knowledge influences performance, academic results, and speed of completing studies ${ }^{20}$.

The initial knowledge possessed by students obtained through the teacher's ability to process the stored information ${ }^{21}$. The teacher needs to know the extent of the students' initial knowledge so that if the initial experience is good enough, then there is no need to be discussed in learning ${ }^{22}$. In this study, initial knowledge measured through an analysis of the results of the pretest test. The test questions are in the form of multiple-choice questions given to students before the discovery learning model, and the conventional learning model is applied. It intended that researchers know the extent of students' fundamental knowledge in the two sample classes about the material to be taught.

\section{Learning Outcomes}

Changes in behavior mark learning outcomes. Although not all changes in behavior are learning outcomes, learning activities generally accompanied by changes in behavior ${ }^{23}$. Learning outcomes must be observable and supported by a type of test called a learning outcome test. Learning outcomes are the results obtained by students after learning activities ${ }^{24}$. Learning outcomes also said as the success of the learning system. The success of learning determined by the product side and the process side. Learning success that only seen from one side will not be perfect ${ }^{25}$. 
Based on the above understanding, it obtains a knowledge that learning outcomes are the actual abilities possessed by students after learning, which manifests in the form of cognitive, affective, and psychomotor skills. In this research, learning outcomes are only limited to the cognitive realm that refers to the Krathwol-Anderson taxonomy covering C1 through C6 (remembering, understanding, applying, analyzing, evaluating, and making).

Learning outcomes measured through analysis of the results of the posttest. The test questions are in the form of multiple-choice questions that are the same as the pretest questions and are given to students after the discovery learning model and the conventional learning model applied. It intended that researchers know the effect of using the two learning models in improving student learning outcomes.

\section{Moment of Force (torque)}

Torque is also called the moment of force and is a vector quantity. Torque is the result per cross between the position vector $\mathrm{r}$ and the force F, which can be written.

$$
\vec{\tau}=\vec{r} \times \vec{F}
$$

The formula states the amount of torque:

$$
\tau=r F \sin \theta
$$

Where $\theta$ is the angle between direction $\vec{r}$ and direction $\overrightarrow{\boldsymbol{F}}$.

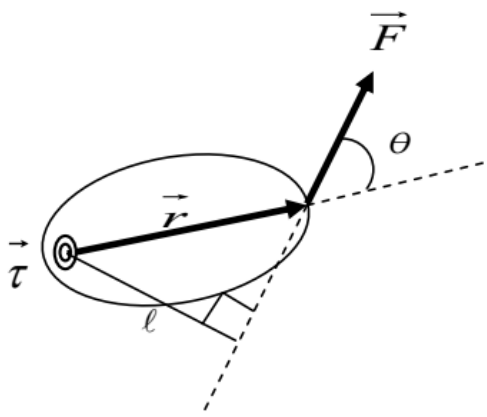

Figure1. Torque

From Figure 1, it appears that the length of the torque arm expressed as

$$
\ell=r \sin \theta
$$

So, equation (3) can be written as

$$
\tau=F \ell
$$

The torque arm is defined as the distance from the axis of rotation to the workforce line, as shown in Figure 1.

\section{Moment of Force (torque)}

The moment of inertia of a particle with mass $m$ defined as the product of the mass of the particle $(m)$ with the square of the perpendicular distance of the particle from the pivot point $\left(r^{2}\right)$.

$$
I=m r^{2}
$$

Because the moment of inertia $I$ in rotational motion is analogous to mass $\mathrm{m}$ in translational motion, the function of the moment of inertia is the same as the function of mass. If the mass in translational motion represents a measure of the ability of an object to maintain its linear velocity, the moment of inertia of an object in rotational motion represents a measure of the strength of an object to retain its rotational angular speed.

\section{The Law of Conservation of Angular Momentum in Rotation Motion}

In rotational motion, analogous to linear momentum is angular momentum. Mass is comparable to the moment of inertia; the linear velocity is similar to angular velocity, then angular momentum $L$ is equal to the result of the moment of inertia $I$ with angular velocity $\omega$.

$$
L=I \omega
$$

Thus, the law of conservation of angular momentum for rotating objects: "If the total torque acting on the object rotates to zero, then the total angular momentum of the object remains/is constant."

\section{E. Balance of Rigid Bodies}

A rigid body is in static equilibrium if at first, the object is at rest, and the resultant force on the object is zero, and the torque to any random point chosen as the axis is zero. Mathematically, it stated as follows: 


$$
\begin{aligned}
& \sum F=0 \\
& \sum \tau=0
\end{aligned}
$$

\section{F. Center for Gravity}

Every particle in a rigid body has weight. The overall weight of an object is the resultant of all downward directed gravity of all particles. This resultant works through a single point called the center of gravity (center of gravity).

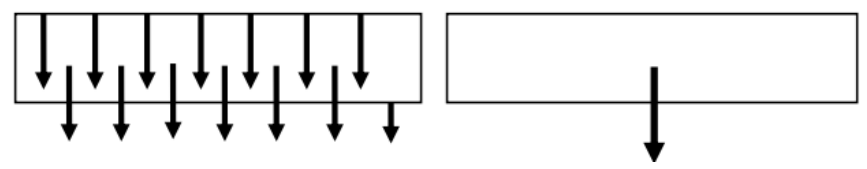

Figure 2. The concept of emphasis

The center of gravity can also express as a point where the resultant gravitational force of the particles concentrated at that point. Therefore, the resultant torque of the gravitational force of particles at their center of gravity must be zero.

\section{METHODOLOGY}

\section{A. Research Model}

This study uses a quasi-experimental design consisting of nonequivalent (pretest-posttest) control group design, in which there are control classes and innovative classes that given different treatments. The procedure of this research is the test of questions at a level that has previously studied the material. In the sample class, a pretest conducted to determine the students' initial ability, treatment, and, finally, the posttest to find out the learning outcomes of students after surgery.

Table 1. Research design

\begin{tabular}{|c|c|c|c|}
\hline Group & Pre-test & Treatment & Post-test \\
\hline Experiment & $\mathrm{R}_{1}$ & $\mathrm{X}$ & $\mathrm{R}_{2}$ \\
\hline Control & $\mathrm{R}_{1}$ & $\mathrm{Y}$ & $\mathrm{R}_{2}$ \\
\hline
\end{tabular}

\section{B. Research Subjects}

In this research conducted students of class XI odd semester of Senior High School 1 Talibura in the academic year 2019/2020. A simple random sampling technique was used in the sampling to obtain class XI 1 MIA as an experimental class and class XI 2 MIA as a control class. Is each course taken as many as 24 students.

\section{Analysis Techniques}

Before testing the hypothesis, the prerequisite test is in the form of a normality test using the Shapiro Wilk test and a homogeneity test using the Fisher test. If the prerequisite tests have completed, then the next hypothesis test is performed using an ANCOVA test.

\section{RESULT}

Based on the test results on the questions in class XII MIA Senior High School 1 Talibura, ten items obtained eight valid items with high reliable status. In the calculation of different power, one problem is excellent, two is good, four is enough, and three is terrible. In the calculation of the difficulty level, eight problems with medium difficulty level and two difficult questions obtained. From some estimates on the test items collected, six items used in the research sample. The initial knowledge of the experimental class students shown in Figure 3. 


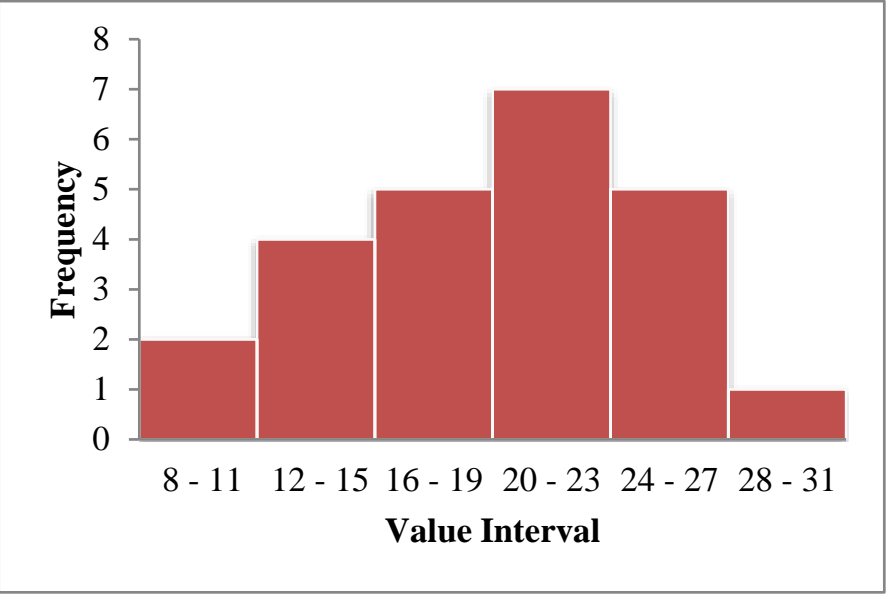

Figure 3 Frequency distribution of initial knowledge of experimental class students

Based on Figure 3, it can be that most students in the experimental class get grades between 20-23. As many as two students got the lowest ranks of 8-11, and 1 student got the highest score of 28-31.The fundamental knowledge of the control class students shown in Figure 4.

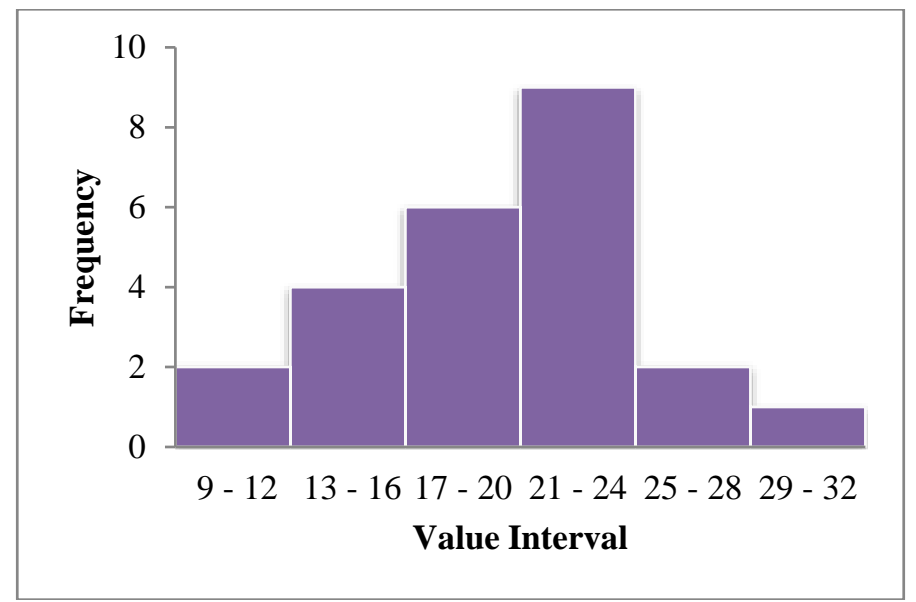

Figure 4. Frequency distribution of initial knowledge of control class students

Based on Figure 4, it can be that most students in the control class get grades between 21-24. As many as two students got the lowest grades 9-12, and 1 student got the highest grades 29-32.Student learning outcomes of the experimental class shown in Figure 5.

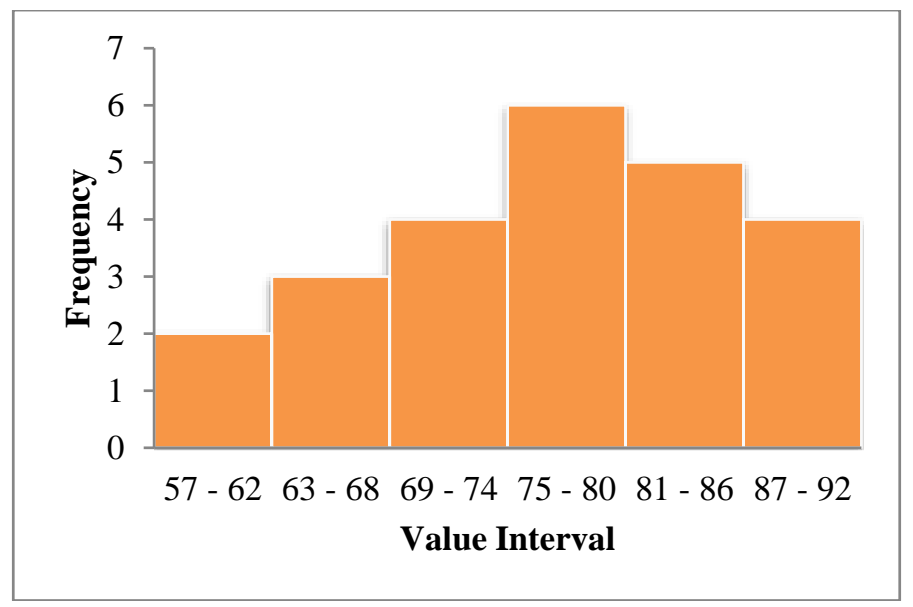

Figure 5 Frequency distribution of student learning outcomes in the experimental class 
Used Figures 5 is seen that most students in the experimental class get grades between $75-80$. A total of 2 students received the lowest score of 57-62, and 4 students received the highest score of 87-92 - the control class student learning outcomes in Figure 6.

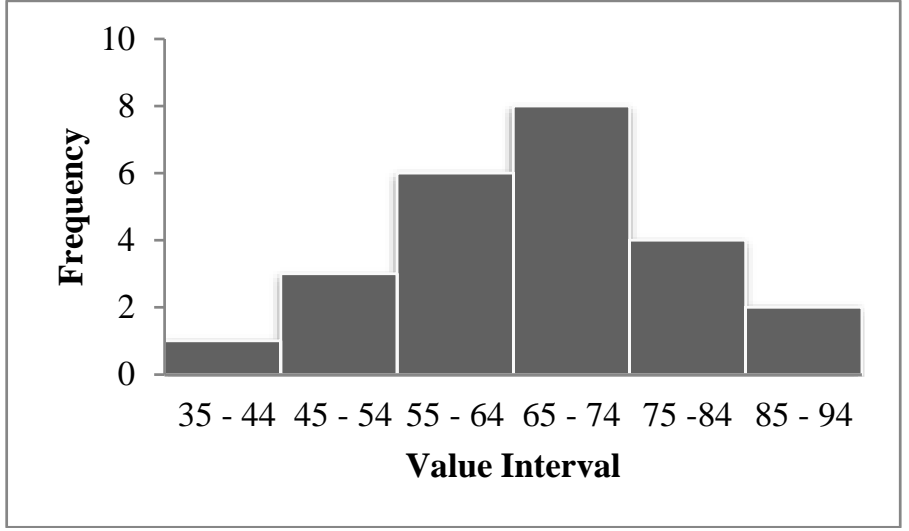

Figure 6 Frequency distribution of learning outcomes of control class students

Based on Figure 6, it can be that most students in the control class get grades between 48-56. A total of 4 students received the lowest ranks of 30-38, and 1 student received the highest degree of 75-83. The results of the normality test in the experimental class and the control class shown in Table 2.

Table 2. Normality Test Results in the Experiment Class and Control Class

\begin{tabular}{|c|c|c|c|}
\hline Variable & Experiment & Control & Conclusion \\
\hline Early knowledge & 0,272 & 0,514 & Data normally distributed \\
\hline Learning outcomes & 0,186 & 0,443 & Data normally distributed \\
\hline
\end{tabular}

Based on Table 2, the initial knowledge of the experimental class and control class students were 0,272 and 0,514 , respectively. Test the normality of the value of student learning outcomes in the innovative class and power class students, respectively 0,186 and 0,443 . Both fundamental knowledge and learning outcomes data obtained in both types stated to generally distributed because the significance collected is higher than the 0,05 significance level. Homogeneity test results in the experimental class and the control class shown in Table 3.

Table 3. Homogeneity Test Results

\begin{tabular}{|c|c|c|c|}
\hline Variable & Sig. & Significance level & Conclusion \\
\hline Early knowledge & 0,875 & 0,05 & Homogeneous variant \\
\hline Learning outcomes & 0,134 & 0,05 & Homogeneous variant \\
\hline
\end{tabular}

Based on Table 3, fundamental knowledge and learning outcomes are 0,875 and 0,134, respectively. Because the significance obtained is higher than 0,05 , it stated that the initial knowledge data and learning outcomes have homogeneous variants. The results of hypothesis testing using the ANCOVA test shown in Table 4.

Table 4. ANCOVA test

\begin{tabular}{|l|r|r|r|r|c|}
\hline Source & Type III Sum of Squares & df & Mean Square & \multicolumn{1}{c|}{ F } & Sig. \\
\hline Corrected Model & $1251,013^{\mathrm{a}}$ & 2 & 625,506 & 4,484 &, 017 \\
\hline Intercept & 14911,884 & 1 & 14911,884 & 106,890 &, 000 \\
\hline Early_Knowledge & 60,992 & 1 & 60,992 &, 437 &, 512 \\
\hline Learning_Model & 1204,084 & 1 & 1204,084 & 8,631 &, 005 \\
\hline Error & 6277,800 & 45 & 139,507 & & \\
\hline Total & 249071,000 & 48 & & & \\
\hline Corrected Total & 7528,813 & 47 & & & \\
\hline
\end{tabular}

Based on Table 4, values of $\mathrm{df} 1=2$ and $\mathrm{df} 2=47$ are obtained so that the value of $\mathrm{F}_{\text {table }}=3,20$ is obtained. In the ANCOVA test, results obtained $F_{\text {count }}$ higher than $F_{\text {table }}(4,484>3,20)$ with a significant value obtained is smaller than the significance level $(0,017<$ 0,05).From these results, concluded that the discovery-assisted used discovery learning model is effective in improving physics learning outcomes in terms of students' initial knowledge 


\section{DISCUSSION}

Based on the results of the study, note the influence of the use of discovery learning models on student physics learning outcomes on the material balance and dynamics of rotation. The discovery learning model applied in the experimental class can influence student learning outcomes much better than the use of conventional learning models in the control class. The increase in physics learning outcomes in the innovative type using the discovery learning model is much higher compared to the control class using the conventional learning model even though the knowledge possessed by students in both categories is almost the same. Therefore, it can conclude that the discovery-assisted discovery learning model has more contribution to improving physics learning outcomes than conventional models.

Based on the results of data analysis, the normality test of the pretest and posttest values in both classes obtained a significant amount that is greater than the significance level 5\%. Therefore, it can conclude that the data using discovery learning models and conventional models come from normally distributed populations. In the homogeneity test conducted, it found that the data had homogeneous variance because it was higher than the significance level of $5 \%$.

Furthermore, in the hypothesis test using ana nova, it was found that the discovery learning model influence on the improvement of physics learning outcomes of students of class XI MIA Senior High School 1 Talibura. The application of the discovery learning model-assisted tracker can make students more active and independent in learning. Different from the classroom learning using conventional models, where students tend to be passive and get bored quickly when studying physics. The test results prove that the physics learning outcomes obtained by students greatly influenced by the application of learning models in the class. In this case, the discovery-assisted discovery learning model tracker considered to be more effectively used in physics learning on material balance and rotational dynamics.

\section{CONCLUSION}

This study conducted to determine the effectiveness of the use of discovery-assisted discovery learning models on improving physics learning outcomes. Based on the result of the hypothesis test, it can conclude that the discovery learning model assisted by tracker considered more useful to be used in physics learning on the material balance and dynamic of rotation compared to using conventional learning models.

\section{ACKNOWLEDGMENT}

The author, with all humility, expresses abundantly thanks to all those who have contributed to this research.

\section{REFERENCES}

[1] H. D. Young, R. A Freedman, and L. Ford, Sears, and Zemansky's University Physics With Modern Physics. US: Eddison-Wesley, 2008.

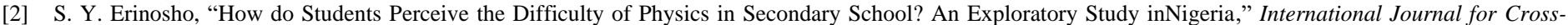
Disciplinary Subjects in Education, vol. 3. 2013, pp. 1510-1515.

[3] B. Suryobroto, Proses Belajar Mengajar di Sekolah. Jakarta: Rineka Cipta, 2009.

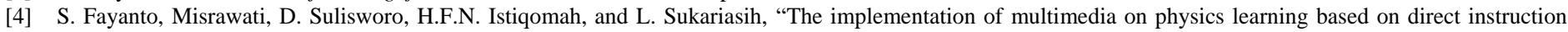
model in the topic of light," Indonesia Journal of Learning Education and Counseling, vol. 1, 2019, pp. 124-132.

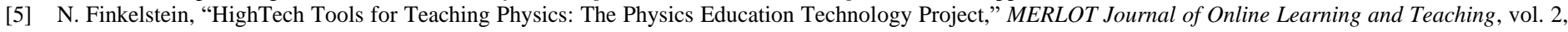
2006, pp. 1-29.

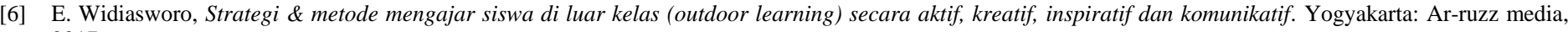
2017.

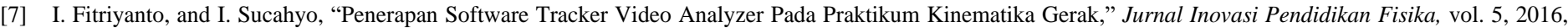
pp. $92-97$.

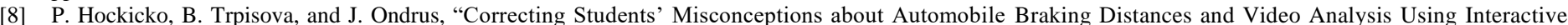
Program Tracker," Journal of science education and tecnology, vol. 23, 2014, pp. 763-776.

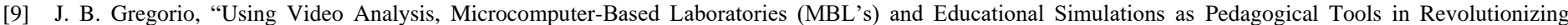
Inquiry Science Teaching and Learning," K-12 STEM Education, vol. 1, 2015, pp. 43-64.

[10] G. Singaravelu, "Discovery Learning Strategies in English,” Journal on English Language Teaching, vol. 2, 2012, pp. 57-62.

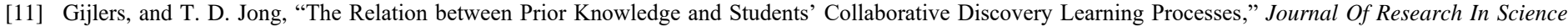
Teaching, vol. 42, 2005, pp. 264-282.

[12] Daryanto, Pendekatan Pembelajaran Saintifik Kurikulum 2013. Yogyakarta: Gava Media, 2014.

[13] M. Dimyati, Belajar dan Pembelajaran. Jakarta: Rineka Cipta, 2006.

[14] W. Sanjaya, Perencanaan dan Desain Sistem Pembelajara. Jakarta: Kencana Prenada Media Group, 2008.

[15] Ruseffendi, Dasar-dasar Penelitian Pendidikan \& Bidang Non-Eksata Lainnya. Bandung: Tarsito, 2005.

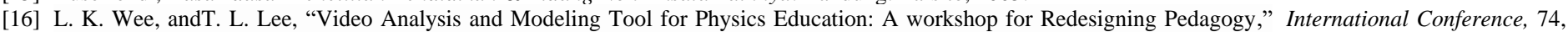
2011.

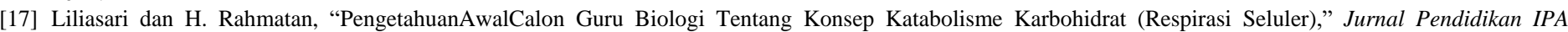
Indonesia, vol. 1, 2012, pp. 91-99.

[18] D. Fiser, andN. Frey, Background Knowledge: The Overlooked Factor in Reading Comprehension. New York: McGraw Hill, 2013.

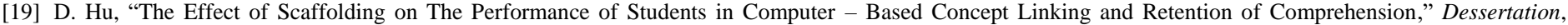
Submitted for publication.

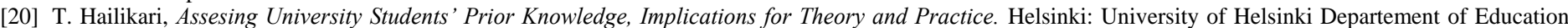
Research Report 227, 2009.

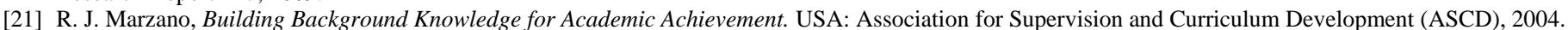

[22] B. A. Pribadi, Model ASSURE untuk Mendesain Pembelajaran Sukses. Jakarta: PT Dian Rakyat, 2011. 
[23] Aunurrahman, Belajar dan Pembelajaran. Bandung: Alfabeta, 2014.

[24] S.B. Djamarah, dan A. Zain, Strategi Belajar Mengajar. Jakarta: PT Asdi Mahastya, 2006.

[25] W. Sanjaya, Perencanaan dan Desain Sistem Pembelajaran. Jakarta: Kencana Prenada Media Group, 2008.

\section{AUTHORS}

First Author - Nurfadila, Student, Universitas Ahmad Dahlan, Email. dilafadilah129@gmail.com

Second Author - Dwi Sulisworo, Lecture in Universitas Ahmad Dahlan, Email. sulisworo@ gmail.com

Third Author - Guntur Maruto, Lecture in Universitas Ahmad Dahlan.

Fourth Author - Suritno Fayanto, Alumnus in Master of Physic Education, Universitas Ahmad Dahlan, Email. suritnofayanto@gmail.com

Correspondence Author - dilafadilah129@gmail.com 